\title{
Determination of the toxicity of the freshwater cyanobacterium Woronichinia naegeliana (Unger) Elenkin
}

\author{
Beata Bober $^{1}$ - Jan Bialczyk ${ }^{1}$
}

Received: 20 July 2016 / Revised and accepted: 15 January 2017 /Published online: 3 February 2017

(C) The Author(s) 2017. This article is published with open access at Springerlink.com

\begin{abstract}
Cyanobacterial blooms are undesirable for ecological and health reasons. While Woronichinia naegeliana is a cyanobacterial species that appears frequently in freshwater, information about it is limited. An evaluation of its toxicity was conducted via tests based on the crustaceans Thamnocephalus platyurus and Daphnia pulex. The greatest effect of the aqueous extract obtained from W. naegeliana cells was observed for T. platyurus. The denoted semi-lethal concentration $\left(\mathrm{LC}_{50}\right)$ after $24 \mathrm{~h}$ of exposure was $0.99 \mathrm{mg}$ of dry weight (d.w.) $\mathrm{mL}^{-1}$. A lower toxicity was displayed for D. pulex, although it grew with time. Among the 18 fractions separated from cyanobacterial extract, only one containing the microginin FR3 (MG-FR3) displayed biological activeness against $T$. platyurus. The remaining products synthesized by $W$. naegeliana displayed an absence or a low level of toxicity making it impossible to determine the $\mathrm{LC}_{50}$ value. Detailed research revealed that MG-FR3 did not affect the activity of enzymes such as trypsin, chymotrypsin, elastase and thrombin, which indicates another mode of action. The results demonstrated that blooms of $W$. naegeliana showed toxic activity towards invertebrate zooplankton.
\end{abstract}

Keywords Bioassays $\cdot$ Cyanobacteria $\cdot$ Cyanopeptides $\cdot$ Microginins

Beata Bober

beata.bober@uj.edu.pl

1 Department of Plant Physiology and Development, Faculty of Biochemistry, Biophysics and Biotechnology, Jagiellonian University, Gronostajowa 7, 30-387 Krakow, Poland

\section{Introduction}

The intensification of cyanobacterial mass occurrences in various aquatic environments is observed worldwide. Cyanobacterial blooms are serious problems, particularly for reservoirs that are a source for potable water. Cyanobacteria are known for the production of a wide range of secondary metabolites of various structure and biological activity. Among them are compounds affecting the taste and odour of water (e.g. 2-methylisoborneol [MIB] and geosmin), toxins (e.g. alkaloids, cyclic peptides) and oligopeptides, whose biological function is unclear (see references in Smith et al. 2008). Although cyanobacteria are capable of simultaneous synthesis of several compounds, only a few are dominant. Generally, cyanobacteria are recognized as toxic if they possess the ability to produce neurotoxins (e.g. anatoxin-a), dermatotoxins (e.g. aplysiatoxin) or hepatotoxins (e.g. microcystins) (Burkholder and Gilbert 2006). This classification does not concern the synthesis of some oligopeptides that contain unusual amino acids in their structures and are considered 'non-toxic', although some of them have been recognized as protease inhibitors. The strong inhibitory activity of cyanobacterial peptides against animal digestive proteases (e.g. elastase, chymotrypsin, trypsin) might indicate their function as anti-grazing factors, whereas the inhibition of thrombin activity, final coagulation protease, might be useful from a medical point of view in designing of new drugs (see references in Chlipala et al. 2011).

The monitoring of potential threats caused by cyanobacterial blooms relies on confirmation of the presence of toxins using mostly analytical methods. However, the application of chemical methods is often complicated due to the lack of appropriate equipment, operational procedures or commercially available standards for compounds. In addition, based only on the results obtained from chemical analyses, it is difficult to exclude the 
synergic effects of several toxic and non-toxic compounds released by cyanobacteria. Jungmann (1992) showed that fractions isolated from the extract of Microcystis aeruginosa cells that did not contain hepatotoxic microcystin-LR appeared to be more toxic to Daphnia sp. than those containing the compound. These may be the most probable reasons why an application of bioassays for evaluation of the bioactivity of all secondary metabolites synthesized by cyanobacteria increases in time. Additionally, relatively simple procedures keep the costs of these routinely performed analyses relatively low (Törökné et al. 2007).

Out of all the cyanobacterial species commonly occurring in water reservoirs, the most widely characterized are those frequently described as toxic (Sivonen and Jones 1999). Although blooms of the cyanobacterium Woronichinia naegeliana belonging to the Chroococcales also appear more frequently in the phytoplankton of freshwater worldwide; information about this species is limited. This is likely due to difficulties in the cultivation of this species under laboratory conditions (Rajaniemi-Wacklin et al. 2005). Bober et al. (2011) reported determination of compounds produced by $W$. naegeliana. The majority of its identified secondary metabolites belong to three classes of oligopeptides: microginins, cyanopeptolins and anabaenopeptins. The extract also contained trace amounts of microcystin-LR. Some studies of W. naegeliana report contradictory data about its toxicity (Rajaniemi-Wacklin et al. 2005, Willame et al. 2005, Baudin et al. 2006, Oberholster et al. 2006). However, in these studies, the main criteria for cyanobacterial biological activity were the presence of microcystins or genes responsible for its production.

Due to potentially significant consequences following the occurrence of W. naegeliana blooms in freshwater and the limited information about its biological activity, this study has been undertaken to determine its toxicity. The toxicity tests used here were based on the crustaceans Thamnocephalus platyurus and Daphnia pulex. These assays are commonly used to evaluate the toxicity of many compounds and are particularly sensitive to cyanobacterial toxins. In addition, assays on separated fractions isolated from cyanobacterial cell extract were performed to determine which compounds are responsible for the biological response. More detailed research including various protease inhibition assays was conducted on the microginin FR3, the dominant compound synthesized by $W$. naegeliana.

\section{Material and methods}

\section{Cyanobacteria}

Woronichinia naegeliana (Unger) Elenkin was collected from Dobczyce reservoir in southern Poland in September 2013.
Identification and isolation were done according to Bober et al. (2011).

\section{Sample preparation}

The cell material was lyophilized and divided into two portions of $1 \mathrm{~g}$ dry weight (d.w.) each. One portion was extracted with $100 \mathrm{~mL}$ Milli-Q water and then filtered through GF/C glass-fibre filters (Whatman, UK). The second portion was used for separation of crude cell extract into fractions containing secondary metabolites according to the procedure described previously (Bober et al. 2011). Briefly, lyophilized cells were extracted with $100 \mathrm{~mL} 100 \%$ methanol under constant shaking and then filtered through a $\mathrm{GF} / \mathrm{C}$ filter. After evaporation to dryness in a nitrogen atmosphere at room temperature, the sample was dissolved in $100 \mathrm{~mL}$ Milli-Q water and concentrated by solid phase extraction with a $\mathrm{C}_{18}$ silica cartridge (Baker Bond, USA). The cartridge was conditioned with $10 \mathrm{~mL} 100 \%$ methanol followed by $10 \mathrm{~mL}$ methanol: $10 \%$ acetic acid $(4: 1 v / v)$. The aqueous sample was passed through at $5 \mathrm{~mL} \mathrm{~min}{ }^{-1}$ flow rate. The cartridge was then washed with $10 \mathrm{~mL}$ portions of 10,20 and $30 \%$ methanol. The eluate, obtained using $10 \mathrm{~mL} 80 \%$ methanol, was evaporated to dryness in a nitrogen atmosphere at room temperature and dissolved in $1 \mathrm{~mL}$ Milli-Q water for analysis using a Waters Inc. (USA) high-performance liquid chromatography system containing a $600 \mathrm{E}$ gradient pump, 717 plus autosampler, a Jetstream 2 plus column thermostat, 996 photodiode array detector and Millenium ${ }^{32}$ SS Software with PDA option. Separation of extract was achieved using a Symmetry $\mathrm{C}_{18}$ column $(4.6 \times 250 \mathrm{~mm} ; 5 \mu \mathrm{m}$; Waters, USA) maintained at $23{ }^{\circ} \mathrm{C}$ and gradient mobile phases consisting of (a) water/trifluoroacetic acid $(0.05 \%, v / v)$ and (b) acetonitrile/ trifluoroacetic acid $(0.05 \%, v / v)$. The elution gradient was changed from 70 to $35 \%$ of eluent A over 35 min at a flow

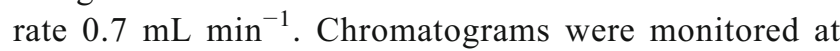
$220 \mathrm{~nm}$. The fractions separated were evaporated to dryness in a nitrogen atmosphere at room temperature and diluted with Milli-Q water to the volume of the extract that was separated; therefore, their concentrations were equivalent to $W$. naegelina biomass concentration. The fractions were analysed using the ULPC-MS/MS system consisting of a Waters ACQUITY UPLC (Waters Inc., USA) coupled with a Waters TQD mass spectrometer (electrospray ionization mode ESI-tandem quadrupole). Chromatographic analyses were performed using the Acquity UPLC BEH (bridged ethyl hybrid) $\mathrm{C}_{18}$ column $(2.1 \times 100 \mathrm{~mm} ; 1.7 \mu \mathrm{m})$ equipped with the Acquity UPLC BEH $\mathrm{C}_{18}$ VanGuard pre-column $(2.1 \times 5 \mathrm{~mm} ; 1.7 \mu \mathrm{m})$. The column was maintained at $40{ }^{\circ} \mathrm{C}$ and eluted using mobile phases consisting of (a) water/formic acid $(0.1 \%, v / v)$ and (b) acetonitrile/formic acid $(0.1 \%, v / v)$. Gradient conditions changed from 95 to $0 \%$ of eluent A over $10 \mathrm{~min}$ at a flow rate of $0.3 \mathrm{~mL} \mathrm{~min}{ }^{-1}$. The MS operational 
conditions were as follows: source temperature of $150{ }^{\circ} \mathrm{C}$, desolvation temperature of $350^{\circ} \mathrm{C}$, desolvation gas flow rate of $600 \mathrm{~L} \mathrm{~h}^{-1}$, cone gas flow of $100 \mathrm{~L} \mathrm{~h}^{-1}$, capillary potential of $3.00 \mathrm{kV}$ and cone potential of $20 \mathrm{~V}$. Nitrogen was used for both the nebulizing and drying gas. The data were obtained in a scan mode ranging from 50 to $2000 \mathrm{~m} / \mathrm{z}$. Target ions selected for MS/MS analyses were fragmented with a collisionactivated dissociation energy of $40 \mathrm{eV}$. The ion spectra were obtained by scanning from the 50 to $1100 \mathrm{~m} / \mathrm{z}$ range. The MassLynx V 4.1 (Waters Inc., USA) software was used for data evaluation. The identities of the compounds presented in each fraction were determined according to Bober et al. (2011).

\section{Toxicity assays}

The dilution series of the aqueous crude extract and separated fractions were prepared with appropriate exposure media in the range of 0.1 to $10 \mathrm{mg}$ d.w. $\mathrm{mL}^{-1}$. The evaluation of cyanobacterial extract toxicity was performed through the application of commercially available acute toxicity assays based on the crustaceans Thamnocephalus platyurus (THAMNOTOXKIT F) and Daphnia pulex (DAPHNOTOXKIT F) following the respective standard operational procedures (Microbiotests Inc., Belgium). The quantitative importance of the toxic effects was calculated as a $50 \%$ effective concentration. Mortality $\left(\mathrm{LC}_{50}\right)$ of $T$. platyurus larvae was recorded after exposure to the cyanobacterial extract for $24 \mathrm{~h}$, whereas dead and immobile $\left(\mathrm{EC}_{50}\right)$ D. pulex were estimated after 24 and $48 \mathrm{~h}$. In both assays, appropriate exposure media were used as a control. The bioassays were considered valid if the mortality or immobilization of test organisms in the controls did not exceed $10 \%$. The toxicity of separated fractions was performed only against $T$. platyurus.

\section{Enzyme inhibition assays}

Detailed analysis of the toxicity mechanism used for the following enzymes, trypsin, chymotrypsin, elastase and thrombin, was performed only for the fraction, which gave a positive result in the crustaceans' bioassays. This fraction was dissolved in ethanol and then diluted in appropriate buffers to perform the respective enzyme assays.

\section{Trypsin inhibition assays}

Inhibition assays of trypsin (EC 3.4.21.4) were performed according to the modified method of Reshef and Carmeli (2001). Trypsin was dissolved in $50 \mathrm{mM}$ TRIS-HCl/ $100 \mathrm{mM} \mathrm{NaCl} / 1 \mathrm{mM} \mathrm{CaCl}_{2} \mathrm{pH} 7.5$ to prepare $1 \mathrm{mg} \mathrm{mL}^{-1}$ solutions. This buffer was also used for the preparation of the $2 \mathrm{mM}$ substrate solution of $N$-benzoyl-D,L-arginine- $p$ nitroanilide. The reaction mixture, which contained $100 \mu \mathrm{L}$ of buffer, $10 \mu \mathrm{L}$ of enzyme solution and $10 \mu \mathrm{L}$ of test solution, was added to a microtiter plate well and pre-incubated at $37^{\circ} \mathrm{C}$ for $5 \mathrm{~min}$ followed by the addition of $100 \mu \mathrm{L}$ substrate solution. The absorbance of the solutions was measured immediately at $405 \mathrm{~nm}$ and after 30 -min incubation at $37^{\circ} \mathrm{C}$.

\section{Chymotrypsin inhibition assays}

Inhibition assays of chymotrypsin (EC 3.4.21.1) were performed according to the method of Kisugi and Okino (2009). Briefly, chymotrypsin was dissolved in $50 \mathrm{mM}$ TRIS-HCl pH 7.6 to prepare a $15 \mathrm{U} \mathrm{mL}^{-1}$ solution. This buffer was used for the preparation of the $1 \mathrm{mg} \mathrm{mL}^{-1}$ substrate solution of $N$-succinyl-L-phenylalanyl- $p$-nitroanilide. The reaction mixture, which contained $30 \mu \mathrm{L}$ of buffer, $50 \mu \mathrm{L}$ of enzyme solution and $10 \mu \mathrm{L}$ of test solution, was added to a microtiter plate well and pre-incubated at $37^{\circ} \mathrm{C}$ for $5 \mathrm{~min}$, followed by the addition of $100 \mu \mathrm{L}$ substrate solution. The absorbance of the solutions was measured immediately at $405 \mathrm{~nm}$ and after 30-min incubation at $37^{\circ} \mathrm{C}$.

\section{Elastase inhibition assay}

This inhibition assay was determined by modifying the method described by Grach-Pogrebinsky et al. (2003). The reaction mixture, which contained $150 \mu \mathrm{L}$ of $0.2 \mathrm{M}$ TRIS-HCl buffer $(\mathrm{pH} 8.0), 10 \mu \mathrm{L}$ of elastase (EC 3.4.21.36) $(0.0075 \mathrm{mg} / \mathrm{mL}$ in $0.2 \mathrm{M}$ TRIS-HCl buffer ( $\mathrm{pH} 8.0)$ ) and $10 \mu \mathrm{L}$ of test solution, was added to each microtiter plate well. Then, the mixture was pre-incubated at $30{ }^{\circ} \mathrm{C}$ for $20 \mathrm{~min}$, and $30 \mu \mathrm{L}$ of $N$-succinylAla-Ala-Ala- $p$-nitroanilide ( $2 \mathrm{mM}$ in $0.2 \mathrm{M}$ TRIS- $\mathrm{HCl}$ buffer ( $\mathrm{pH}$ 8.0)) was added. The absorbance of the solutions was read immediately at $405 \mathrm{~nm}$ and after incubation at $30{ }^{\circ} \mathrm{C}$ for $30 \mathrm{~min}$.

\section{Thrombin inhibition assay}

Thrombin (EC 3.4.21.5) inhibitory activity was measured according to Anas (2012). Briefly, the reaction mixture, which contained $90 \mu \mathrm{L}$ of thrombin from bovine plasma $\left(1.3 \mathrm{U} \mathrm{mL}^{-1}\right.$ in $0.15 \mathrm{M}$ TRIS-imidazole ( $\mathrm{pH} 8.2$ ) ) and $20 \mu \mathrm{L}$ of test sample, was pre-incubated at $37^{\circ} \mathrm{C}$ for $5 \mathrm{~min}$. Then, $90 \mu \mathrm{L}$ of Bz-PheVal-Arg-pNa.HCl $\left(200 \mu \mathrm{g} \mathrm{mL}^{-1}\right.$ in $0.2 \mathrm{M}$ TRIS-HCl buffer $(\mathrm{pH} 8.0)$ ) was added to begin the reaction. The absorbance was measured immediately and after incubation at $37{ }^{\circ} \mathrm{C}$ for $30 \mathrm{~min}$.

\section{Chemicals}

All reagents were analytical, HPLC or MS grade and were from Sigma-Aldrich (USA) or delivered within crustacean toxicity screening tests (Microbiotests Inc., Belgium). 
Table 1 Toxicity of the extract from Woronichinia naegeliana cells assessed with crustaceans' bioassays expressed as $50 \%$ effective concentrations $\left(\mathrm{LC}_{50}\right.$-mortality concentration; $\mathrm{EC}_{50}$-mobility inhibitory concentration). Data are expressed as mean $\pm \mathrm{SD}(n=5)$

\begin{tabular}{|c|c|c|c|}
\hline \multicolumn{4}{|l|}{ Extract exposure } \\
\hline Organism & $\begin{array}{r}\text { Time } \\
\text { (h) }\end{array}$ & $\begin{array}{l}\text { Response } \\
\text { type }\end{array}$ & $\begin{array}{l}\text { Concentration (mg dry } \\
\text { weight } \mathrm{mL}^{-1} \text { ) }\end{array}$ \\
\hline $\begin{array}{l}\text { Thamnocephalus } \\
\text { platyurus }\end{array}$ & 24 & $\mathrm{LC}_{50}$ & $0.99 \pm 0.25$ \\
\hline \multirow[t]{2}{*}{ Daphnia pulex } & 24 & $\mathrm{EC}_{50}$ & $5.21 \pm 0.38$ \\
\hline & 48 & $\mathrm{EC}_{50}$ & $2.94 \pm 0.20$ \\
\hline
\end{tabular}

Ultrapure grade water (Milli-Q water) was obtained from Millipore (USA).

\section{Statistical analysis}

Calculations of toxicity assays based on crustaceans were made using probit analysis (U.S. EPA 1985). Briefly, the percentages of toxic effects were plotted against log concentration, and the $50 \%$ effective concentrations were calculated using analysis of regression. Data obtained from enzyme assays were analysed using a sigmoidal dose-response curve and BioDataFit 1.02 software (Chang Bioscience Inc.). All data are expressed as the mean \pm standard deviation (SD) of five replicates.

\section{Results}

\section{Toxicity of $W$. naegeliana cell extract}

Among the test organisms, the greatest biological sensitivity to the effect of the aqueous extract from $W$. naegeliana cells was displayed by T. platyurus (Table 1). The denoted lethal concentration on $50 \%$ of individuals after 24-h exposure to cyanobacterial extract was $0.99 \mathrm{mg}$ d.w. $\mathrm{mL}^{-1}$. The effective concentration of $5.21 \mathrm{mg}$ d.w. $\mathrm{mL}^{-1}$ caused death or immobilization of $D$. pulex. However, two times longer exposure to
Table 2 Percent of dead Thamnocephalus platyurus larvae exposed for $24 \mathrm{~h}$ to separate fractions extracted from $10 \mathrm{mg}$ d.w. $\mathrm{mL}^{-1}$ Woronichinia naegeliana cells. Data are expressed as mean $\pm \mathrm{SD}(n=5)$

\begin{tabular}{|c|c|c|c|}
\hline Fraction & Fraction composition $^{\mathrm{a}}$ & $\begin{array}{l}\text { Retention } \\
\text { time } \\
(\mathrm{min})\end{array}$ & $\begin{array}{l}\text { (\%) of dead } \\
\text { T. platyurus } \\
\text { larvae }\end{array}$ \\
\hline A & Microginin FR3 & 9.2 & $100.0 \pm 0.0$ \\
\hline B & Microginin FR4 & 10.7 & $14.0 \pm 5.5$ \\
\hline $\mathrm{C}$ & Micropeptin T2 & 11.4 & $22.0 \pm 8.4$ \\
\hline $\mathrm{D}$ & Micropeptin 478-B & 12.3 & $16.0 \pm 11.4$ \\
\hline $\mathrm{E}$ & Micropeptin 88D & 12.8 & $30.0 \pm 7.1$ \\
\hline $\mathrm{F}$ & Cyanopeptolin 880 & 13.6 & $20.0 \pm 0.0$ \\
\hline G & Unknown compound $791 \mathrm{Da}$ & 17.0 & $24.0 \pm 5.5$ \\
\hline $\mathrm{H}$ & Microginin 757 & 18.1 & $16.0 \pm 5.5$ \\
\hline I & $\begin{array}{l}\text { Cyanopeptolin 914, unknown } \\
\text { compound } 874 \mathrm{Da}\end{array}$ & 19.0 & $6.0 \pm 5.5$ \\
\hline $\mathrm{J}$ & $\begin{array}{l}\text { Unknown compounds-1013 } \\
\text { and } 973 \mathrm{Da}\end{array}$ & 19.7 & $24.0 \pm 8.9$ \\
\hline $\mathrm{K}$ & $\begin{array}{l}\text { Micropeptin SD999, unknown } \\
\text { compound } 1039 \mathrm{Da}\end{array}$ & 20.4 & $22.0 \pm 8.4$ \\
\hline $\mathrm{L}$ & Unknown compound $1047 \mathrm{Da}$ & 21.8 & $32.0 \pm 4.5$ \\
\hline M & $\begin{array}{l}\text { Microcystin-LR, microginin 91E, } \\
\text { planktopeptin BL1061, } \\
\text { unknown compound } 1123 \mathrm{Da}\end{array}$ & 23.1 & $26.0 \pm 5.5$ \\
\hline $\mathrm{N}$ & $\begin{array}{l}\text { Cyanopeptolin 908, oscillamide } \\
\text { B }\end{array}$ & 24.0 & $10.0 \pm 0.0$ \\
\hline $\mathrm{O}$ & $\begin{array}{l}\text { Cyanopeptolin B, unknown } \\
\text { compound } 888 \mathrm{Da}\end{array}$ & 24.4 & $8.0 \pm 4.5$ \\
\hline $\mathrm{P}$ & $\begin{array}{l}\text { Cyanopeptolin C, unknown } \\
\text { compound } 902 \mathrm{Da}\end{array}$ & 27.2 & $40.0 \pm 7.1$ \\
\hline Q & $\begin{array}{l}\text { Microginin 51A, cyanopeptolin } \\
\text { D, unknown compounds- } \\
1061,1021 \text { and } 812 \mathrm{Da}\end{array}$ & 28.2 & $8.0 \pm 4.5$ \\
\hline $\mathrm{R}$ & Microginin 478 & 30.0 & $8.0 \pm 4.5$ \\
\hline
\end{tabular}

${ }^{\text {a }}$ Fraction composition was determined according to Bober et al. 2011 cyanobacterial extract $(48 \mathrm{~h})$ caused reduction of the effective concentration by 1.77 times.

\section{Toxicity of fractions}

The extract obtained from $W$. naegeliana cells was separated into 18 fractions (Fig. 1) that were used to determine which secondary metabolites are responsible for the toxicity of
Fig. 1 Chromatogram of extract obtained from Woronichinia naegeliana cells monitored at $220 \mathrm{~nm}$. Letters match the fractions described in Table 2

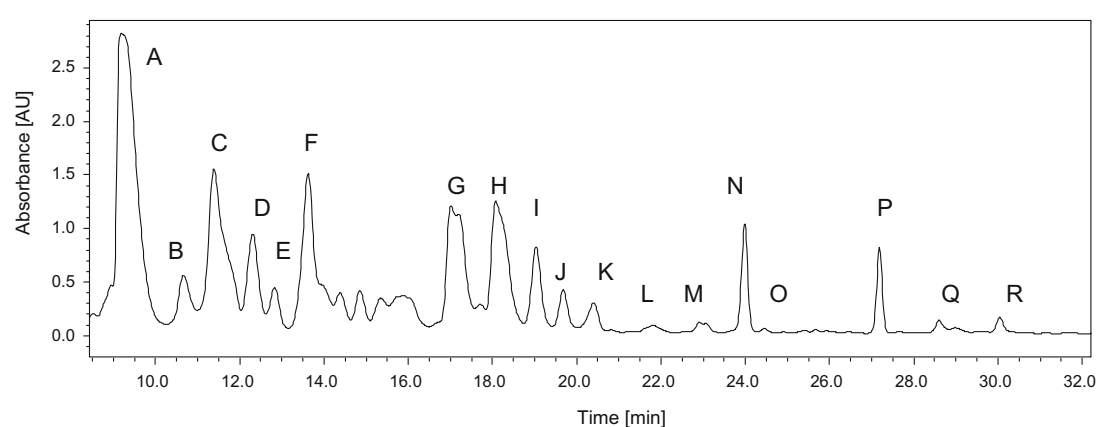


W. naegeliana. The bioactivity assays of separated fractions were based on the crustacean T. platyurus that was found to be more sensitive on cyanobacterial extract than D. pulex. One of the 18 fractions isolated from the cell extract exhibited biological activity in the tested concentration range, and the determined $\mathrm{LC}_{50}$ was equal to its content extracted from $5.34 \mathrm{mg}$ d.w. $\mathrm{mL}^{-1}$ W. naegeliana cells. The remaining fractions containing secondary metabolites displayed a very low or no toxicity making it impossible to determine the $\mathrm{LC}_{50}$ value (Table 2). The bioactive fraction A (Fig. 2) contained pure microginin FR3 (MG-FR3) (purity 99\%) for which determined $\mathrm{LC}_{50}$ was equal to $7.78 \mu \mathrm{g} \mathrm{mL}^{-1}$.

\section{The enzyme inhibitory activity of MG-FR3}

Protease assays including trypsin, chymotrypsin, elastase and thrombin were performed only for the MG-FR3, which gave
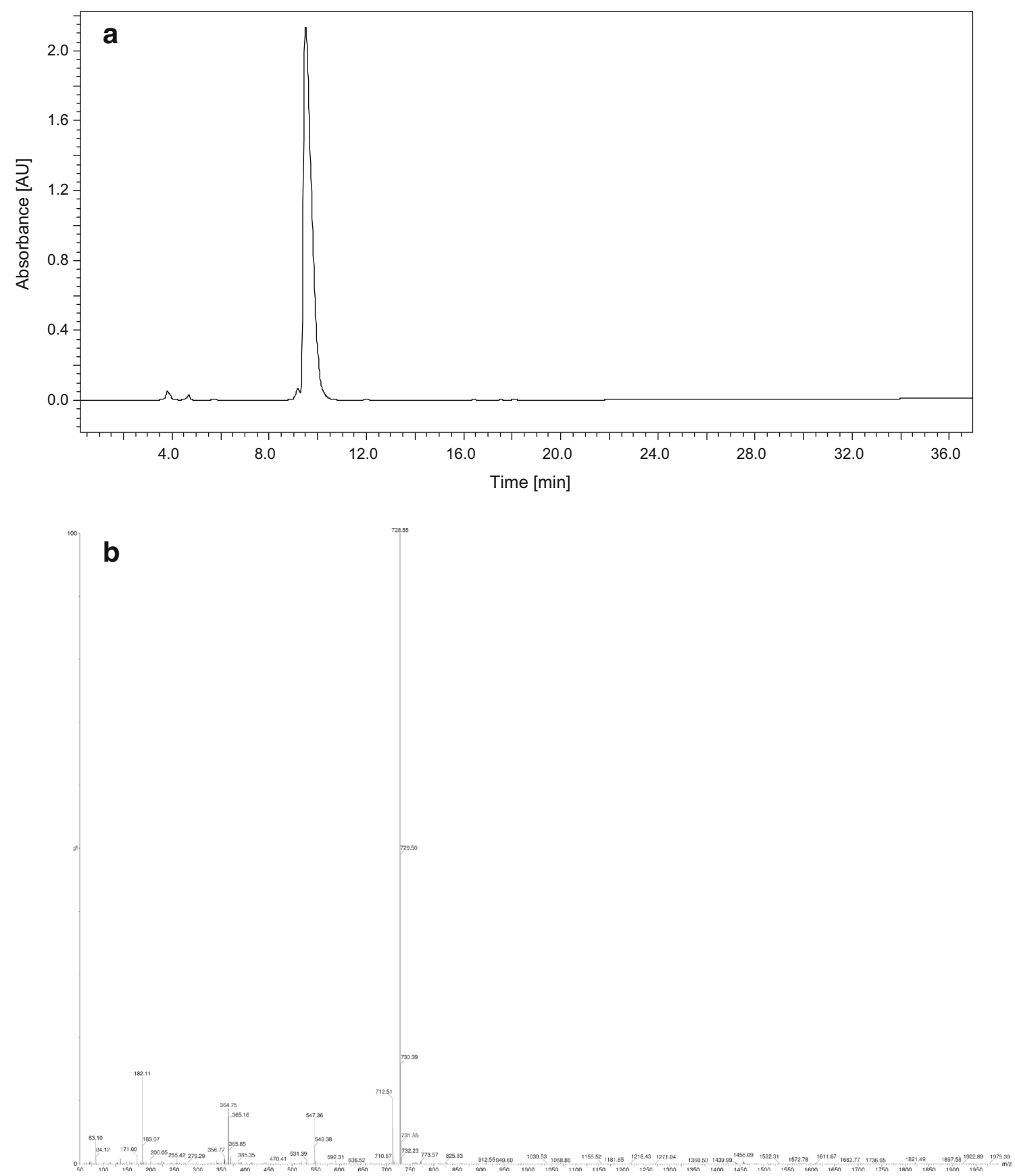

Fig. 2 a Chromatogram of fraction A contained microginin FR3 monitored at $220 \mathrm{~nm}, \mathbf{b}$ ion mass spectrum of microginin FR3 and $\mathbf{c}$ MS/MS product ion spectrum of microginin FR3 (m/z $728.5 \mathrm{Da})$ inside the structure of microginin FR3 


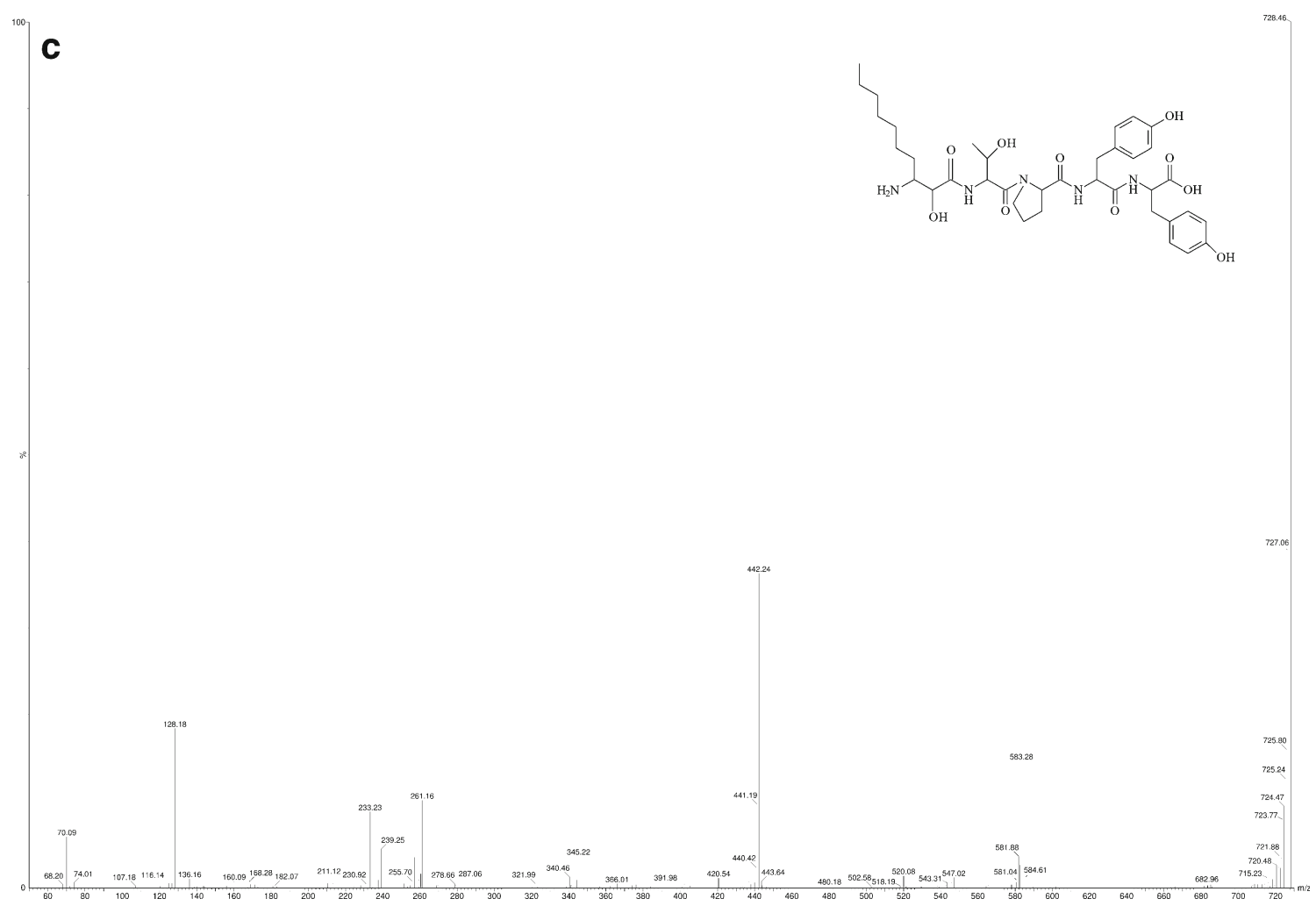

Fig. 2 (continued)

positive result in bioassays with $T$. platyurus. The MG-FR3 did not affect the activity of tested enzymes (Table 3 ).

\section{Discussion}

Results showed different sensitivities of tested crustaceans to aqueous extract from $W$. naegeliana cells. A higher biological response to cyanobacterial extract was observed for T. platyurus rather than for D. pulex (Table 1). These results are consistent with the findings of Marsálek and Bláha (2004), who found that $T$. platyurus revealed the highest sensitivity to cyanobacterial samples among all tested commercially available biotests. A lower sensitivity to cyanobacterial extract was observed for $D$. pulex, although its toxicity increased with time. Woronichinia naegeliana has been described as a potential source of toxin by Scott (1991), but to the best of our

Table 3 The enzyme inhibitory activities of MG-FR3 ( IC $_{50}-50 \%$ inhibitory concentration)

\begin{tabular}{ll}
\hline Enzyme & $\mathrm{IC}_{50}\left(\mu \mathrm{g} \mathrm{mL}^{-1}\right)$ \\
\hline Trypsin & $>40$ \\
Chymotrypsin & $>40$ \\
Elastase & $>40$ \\
Thrombin & $>100$ \\
\hline
\end{tabular}

knowledge, there are no published quantitative data relating to its toxicity. We compared our results with the values presented by Marsálek and Bláha (2004), who applied similar bioassays in the assessment of Microcystis-dominated water blooms. The determined toxicity of $W$. naegeliana cells was classified as average (Table 4 ). In studies presenting data and analyses of samples collected from blooms where $W$. naegeliana was the dominant species among secondary metabolites, different variants of microcystins have been detected (Willame et al. 2005, Baudin et al. 2006). Although a trace amount of microcystin-LR was also detected in the studied material, its toxicity values were higher than those obtained for $M$. aeruginosa cells containing a high amount of this hepatotoxin. Additionally, the neurotoxicity of samples collected from Finnish lakes was statistically associated with the presence of Anabaena lemmermanni, Anabaena flosaquae and $W$. naegeliana cells in the samples (Sivonen et al. 1990). Neurotoxins were not detected in the studied W. naegeliana cells. However, the possibility that the extraction procedure used and the conditions of the liquid chromatography analyses were not optimal for the detection of the neurotoxins cannot be excluded. The divergences in these results might also be due to difficulties in the separation of particular cyanobacterial species from the collected samples.

In the majority of the toxicity tests conducted for the secondary metabolites produced by $W$. naegeliana, their 
Table 4 Comparison of the biological sensitivity of Thamnocephalus platyurus and Daphnia pulex exposed to aqueous extracts from various species of cyanobacteria. Data are presented as was described in Table 1

\begin{tabular}{|c|c|c|}
\hline Cyanobacterial extract & $\begin{array}{l}\text { Thamnocephalus } \\
\text { platyurus } 24-\mathrm{h}_{50} \\
\text { (mg dry weight } \mathrm{mL}^{-1} \text { ) }\end{array}$ & $\begin{array}{l}\text { Daphnia pulex } 24-\mathrm{h} \\
\mathrm{EC}_{50}\left(\mathrm{mg} \mathrm{dry}^{-1}\right. \\
\left.\text { weight } \mathrm{mL}^{-1}\right)\end{array}$ \\
\hline $\begin{array}{l}\text { Woronichinia } \\
\text { naegeliana }^{\mathrm{a}}(99 \%)^{\mathrm{c}}\end{array}$ & $0.99 \pm 0.25$ & $5.21 \pm 0.38$ \\
\hline $\begin{array}{l}\text { Microcystis aeruginosa } \\
\quad(98 \%)^{\mathrm{c}}\end{array}$ & $0.11 \pm 0.3$ & $1.1 \pm 1.2$ \\
\hline $\begin{array}{l}\text { Microcystis ichtyoblabe } \\
(75 \%)^{\mathrm{c}} \text { and } \\
\text { M. aeruginosa } \\
(20 \%)^{\mathrm{c}}\end{array}$ & $0.35 \pm 0.1$ & $2.1 \pm 1.2$ \\
\hline $\begin{array}{l}\text { Microcystis } \\
\quad \text { wesenbergii }{ }^{\mathrm{b}}(98 \%)^{\mathrm{c}}\end{array}$ & $3.7 \pm 1.9$ & $12.3 \pm 2.6$ \\
\hline
\end{tabular}

${ }^{\text {a }}$ Data obtained in this study

${ }^{\mathrm{b}}$ Data published by Maršálek and Bláha (2004)

${ }^{\mathrm{c}}$ Percent in parenthesis represents the content of a given species in the studied cyanobacterial biomass

biological impact on T. platyurus has not been determined. The exception is for microginin FR3 (Table 2). The difference between the $\mathrm{LC}_{50}$ of separated fractions and that obtained for the total W. naegeliana extract might be the result of the synergic effect of all the compounds. Most of the metabolites synthesized by W. naegeliana (Bober et al. 2011, 2014) belong to several classes of oligopeptides, which non-ribosomal synthesis is a significant part of cell metabolism (Welker and von Döhren 2006). Although their ecological role has not been fully elucidated, their inhibitory activity against proteases indicates that they are able to affect other organisms, even causing cell lysis. As a consequence, they might be a part of a protection strategy in the aquatic ecosystem (see references in Chlipala et al. 2011).

MG-FR3 belongs to the microginins, linear peptides that contain four to six amino acid residues with a characteristic Nterminal residue 3-amino-2-hydroxydecanoic acid (Ahda) and frequently two tyrosine units at the C-terminus (Welker and von Döhren 2006). Some of these oligopeptides have been recognized as leucine aminopeptidase (LAP) inhibitors due to the $2 \mathrm{~S}$ configuration of the Ahda group (Ishida et al. 1997; Neumann et al. 1997). The structure N-Me-Tyr-Tyr at the C-terminus seemed to be crucial for the inhibition of angiotensin-converting enzyme (ACE) (Ishida et al. 2000). The inhibitory activity of some microginins for ACE was considered for the production of blood pressure-decreasing drugs (Kraft et al. 2006). However, some microginins did not show any inhibition activity against trypsin, chymotrypsin, papain, elastase or protein phosphatase 1A (Ishida et al. 1997).

MG-FR3, which was detected in the extract from W. naegeliana cells, induced a biological response in crustaceans and therefore was used in assays including digestive proteases such as trypsin, chymotrypsin and elastase. The results are consistent with reports of other microginins showing that MG-FR3 did not affect the activity of tested enzymes (Table 3). No inhibition of thrombin was observed. Therefore, the observed toxicity of $W$. naegeliana towards planktonic invertebrates seems to be connected to a mode of action other than serine protease inhibition or may be a result of the synergic effect of all the produced cyanopeptides. To date, the significance of these oligopeptides to cyanobacteria metabolism and their biological function is unclear. There are several hypotheses concerning cyanopeptides, including the mechanism of the inhibition of vital enzymes, allelopathic activity on other phytoplankton organisms, chemical grazing protection and involvement in cell metabolism (see references in Halstvedt et al. 2008). However, the modes of action require further investigation.

In conclusion, the biological activity of the poorly studied freshwater bloom forming cyanobacteria $W$. naegeliana towards planktonic invertebrates was studied. The biological effects on planktonic crustaceans were related to a fraction containing MG-FR3. Effective assessment of the environmental risk connected to the occurrence of cyanobacterial blooms should also take into account others than those commonly known to produce toxic secondary metabolites.

Acknowledgements The Faculty of Biochemistry, Biophysics and Biotechnology of Jagiellonian University is a partner of the Leading National Research Center (KNOW) supported by the Ministry of Science and Higher Education.

Open Access This article is distributed under the terms of the Creative Commons Attribution 4.0 International License (http:// creativecommons.org/licenses/by/4.0/), which permits unrestricted use, distribution, and reproduction in any medium, provided you give appropriate credit to the original author(s) and the source, provide a link to the Creative Commons license, and indicate if changes were made.

\section{References}

Anas ARJ (2012) Studies on linear peptides from the freshwater cyanobacteria of genus Anabaena. PhD thesis, Hokkaido University

Baudin I, Cagnard O, Grandguillaume JJ, Do-Quang Z (2006) Algae and associated toxins \& metabolites: methodology for risk assessment and risk management. Wat Pract Technol 1:1-12

Bober B, Lechowski Z, Bialczyk J (2011) Determination of some cyanopeptides synthesized by Woronichinia naegeliana (Chroococcales, Cyanophyceae). Phycol Res 59:286-294

Bober B, Kaminski A, Chrapusta E, Bialczyk J (2014) Stability of some microginins synthesized by the cyanobacterium Woronichinia naegeliana (Unger) Elenkin. Phycol Res 62:228-231

Burkholder JM, Glibert PM (2006) Intraspecific variability: an important consideration in forming generalizations about toxigenic algal species. South Afr J Mar Sci 28:177-180

Chlipala GE, Mo S, Orjala J (2011) Chemodiversity in freshwater and terrestrial cyanobacteria - a source for drug discovery. Curr Drug Targets 12:1654-1673 
Grach-Pogrebinsky O, Sedmak B, Carmeli S (2003) Protease inhibitors from Lake Bled toxic waterbloom of the cyanobacterium Planktothrix rubescens. Tetrahedron 59:8329-8336

Halstvedt CB, Rohrlack T, Ptacnik R, Edvardsen B (2008) On the effect of abiotic environmental factors on production of bioactive oligopeptides in field populations of Planktothrix spp. (Cyanobacteria). J Plankton Res 5:607-617

Ishida K, Matsuda H, Murakami M, Yamaguchi K (1997) Microginins 299-A and -B, leucine aminopeptidase inhibitors from the cyanobacterium Microcystis aeruginosa (NIES-299). Tetrahedron 30: 10281-10288

Ishida K, Kato T, Murakami M, Wanatabe M, Wanatabe MF (2000) Microginins, zinc metalloproteases inhibitors from the cyanobacterium Microcystis aeruginosa. Tetrahedron 56:8643-8656

Jungmann D (1992) Toxic compounds isolated from Microcystis PCC 7806 that are more active against Daphnia than two microcystins. Limnol Oceanogr 37:1777-1783

Kisugi T, Okino T (2009) Micropeptins from the freshwater cyanobacterium Microcystis aeruginosa (NIES-100). J Nat Prod 72:777-781

Kraft M, Schleberger C, Weckesser J, Schulz GE (2006) Binding structure of the leucine aminopeptidase inhibitor microginin FR1. FEBS Lett 580:6943-6947

Marsálek B, Bláha L (2004) Comparison of 17 biotests for detection of cyanobacterial toxicity. Environ Toxicol 19:310-317

Neumann U, Forchert A, Flury T, Weckesser J (1997) Microginin FR1, a linear peptide from a water bloom of Microcystis species. FEMS Microbiol Lett 153:475-478

Oberholster PJ, Botha A-M, Cloete TE (2006) Toxic cyanobacterial blooms in a shallow, artificially mixed urban lake in Colorado, USA. Lakes Reservoirs Res Manag 11:111-123
Rajaniemi-Wacklin P, Rantala A, Mugnai MA, Turicchia S, Ventura S, Komárková J, Lepistö L, Sivonen K (2005) Correspondence between phylogeny and morphology of Snowella spp. and Woronichinia naegeliana, cyanobacteria commonly occurring in lakes. J Phycol 42:226-232

Reshef V, Carmeli S (2001) Protease inhibitors from a water bloom of the cyanobacterium Microcystis aeruginosa. Tetrahedron 57:28852894

Scott WE (1991) Occurence and significance of toxic cyanobacteria in southern Africa. Wat Sci Tech 23:175-180

Sivonen K, Jones G (1999) Cyanobacterial toxins. In: Chorus I, Bartram J (eds) Toxic cyanobacteria in water: a guide to their public health consequences. Monitoring and Management. E\&FN Spon, London, pp 41-111

Sivonen K, Niemelä SI, Niemi RM, Lepistö L, Luoma TH, Räsänen LA (1990) Toxic cyanobacteria (blue-green algae) in Finnish fresh and coastal waters. Hydrobiologia 3:256-275

Smith JL, Boyer GL, Zimba PV (2008) A review of cyanobacterial odorous and bioactive metabolites: impacts and management alternatives in aquaculture. Aquaculture 280:5-20

Törökné A, Vasdinnyei R, Asztalos M (2007) A rapid microbiotest for the detection of cyanobacterial toxins. Environ Toxicol 22:64-68

U.S. EPA (1985) Method for calculation of LC50 values using probit analysis. US-EPA/600/485/013.

Welker M, von Döhren H (2006) Cyanobacterial peptides - nature's own combinatorial biosynthesis. FEMS Microbiol Rev 30:530-563

Willame R, Jurczak T, Iffly J-F, Kull T, Meriluoto J, Hoffmann L (2005) Distribution of hepatotoxic cyanobacterial blooms in Belgium and Luxembourg. Hydrobiologia 551:99-117 